\title{
Knockdown of ROS proto-oncogene I inhibits migration and invasion in gastric cancer cells by targeting the PI3K/Akt signaling pathway
}

This article was published in the following Dove Press journal: OncoTargets and Therapy

\author{
Jingjing Qiao ${ }^{1,2}$ \\ Man $\mathrm{Li}^{2}$ \\ Dan Sun' \\ Wenhui Li' \\ Yan Xin'
}

'Laboratory of Gastrointestinal OncoPathology, Cancer Institute and General Surgery Institute, The First Affiliated Hospital of China Medical University, Shenyang, Liaoning Province II000I, People's Republic of China; ${ }^{2}$ Department of Oncology, The Second Affiliated Hospital of Dalian Medical University, Dalian, Liaoning Province II 6027. People's Republic of China
Correspondence: Yan Xin

Laboratory of Gastrointestinal OncoPathology, Cancer Institute and General Surgery Institute, The First Affiliated Hospital of China Medical University, 155 Nanjing North Street, Heping District, Shenyang, Liaoning Province II000I,

People's Republic of China

Tel +8602483282375

Email yxin@cmu.edu.cn
Objectives: Gastric cancer ranks the fourth most common cancer and the third leading cause of cancer mortality in the world. ROS proto-oncogene 1 (ROS1) is an oncogene and ROS1 rearrangement has been reported in many cancers. Our study aimed to investigate the potential function and the precise mechanisms of ROS1 in gastric cancer.

Methods: In our study, the analysis of ROS1 expression and clinical pathologic factors of gastric cancer in gastric cancer using TCGA database demonstrated that ROS1 expression was elevated in gastric cancer and related to T, N, M and TNM staging. High expression of ROS1 predicted poor survival in patients with gastric cancer. Then, we measured ROS1 expression in four human gastric cancer cell lines and knocked down ROS1 expression in BGC-823 and SGC-7901 cells by specific shRNA transfection via Lipofectamine 2000. The effect of ROS1 knockdown on cell proliferation, cell cycle distribution, cell apoptosis and metastasis in vitro was evaluated by MTT, colony formation, flow cytometric analysis, wound healing and Transwell invasion assays. The levels of apoptosis-related proteins, EMT markers and the PI3K/Akt signaling pathway members were measured by Western blotting.

Results: We demonstrated that $\operatorname{sh} R O S 1$ transfection markedly downregulated ROS1 expression in BGC-823 and SGC-7901 cells. Knockdown of ROS1 inhibited cell survival, clonogenic growth, migration, invasion and epithelial-mesenchymal transition (EMT), as well as induced cell cycle arrest and apoptosis in gastric cancer cells. Furthermore, ROS1 knockdown inhibited the phosphorylation of PI3K and Akt.

Conclusion: Collectively, our data suggest that ROS1 may serve as a promising therapeutic target in gastric cancer treatment.

Keywords: gastric cancer, ROS1, shRNA, proliferation, apoptosis, metastasis, EMT

\section{Introduction}

Gastric cancer is the fourth common malignancies and the third leading cause of cancer death worldwide. ${ }^{1,2}$ Patients are diagnosed at the advanced stages of gastric cancer and 5-year survival rate is no more than $40 \%$ in China. ${ }^{3-5}$ Surgical resection, radiation therapy, chemotherapy and combination treatments are considered as therapeutic approaches for malignancies, including gastric cancer. ${ }^{4}$ Despite this, more than $80 \%$ of the cancer patients develop loco-regional or distant recurrence after curative resection. ${ }^{6}$ Peritoneal dissemination after surgery and lymph node or liver metastasis are still the main factors that contribute to the poor prognosis of gastric cancer. ${ }^{7,8}$ 
ROS1 is an oncogene and encodes a receptor tyrosine kinase (RTK) of insulin receptor family. ${ }^{9,10}$ ROS1 shares $49 \%$ amino acid sequence homology with anaplastic lymphoma kinase (ALK) in tyrosine kinase domains. ${ }^{11,12}$ ROS1 undergoes gene rearrangement and forms protein fusions to exhibit constitutive kinase activities in multiple cancers, such as colon cancer, glioblastoma multiforme, lung cancer and gastric cancer. ${ }^{13-15}$ Targeting ROS1 with tyrosine kinase inhibitor has been approved by the FDA for the treatment of advance ROS1-positive NSCLC. ${ }^{16}$ Tiash $\mathrm{S}$ et al reported that ROS1 knockdown enhanced the sensitivity of breast cancer cells to doxorubicin in vivo and in vitro. ${ }^{17}$ Deng $\mathrm{G}$ et al demonstrated that downregulation of ROS1 using shRNA inhibited cell proliferation, migration and invasion and induced cell apoptosis in intrahepatic cholangiocarcinoma cells. ${ }^{18}$ However, few studies have reported the effects of ROS1 on gastric cancer and investigated the precise mechanisms.

In the present study, we knocked down ROSI expression in gastric cancer BGC-823 and SGC-7901 cells and further evaluated the effects of ROS1 knockdown on gastric cancer cell proliferation, colony formation, apoptosis, migration, invasion and epithelial-mesenchymal transition (EMT).

\section{Materials and methods}

\section{Analysis of The Cancer Genome Atlas (TCGA) database}

RNA-Seq data of ROS1 expression, related clinicopathologic factors and prognosis information of patients with gastric cancer included total 415 gastric cancer and 35 normal mucosa samples were obtained from TCGA (https://portal.gdc.cancer.gov/).

\section{Cell culture}

Human gastric cancer BGC-823, MGC-803, SGC-7901 and HGC-27 cells were purchased from Shanghai Zhong Qiao Xin Zhou Biotechnology (Shanghai, China). All the cells were cultured in RPMI-1640 containing 10\% FBS and placed in a $5 \% \mathrm{CO}_{2}$ incubator at $37^{\circ} \mathrm{C}$.

\section{Construction of shRNA plasmid and cell transfection}

The nucleotide sequences were used: $\operatorname{sh} R O S 1$-sense, 5'-GA TCCCCGAGCCAATG TCATCCTGATTTCAAGAGAATC AGG ATGACATTGGCTCTTTTT-3' and antisense, 5'-AGC TAAAAAGAGCCAATGTCATCCTGATTCTCTTGAAATCAGGATGACATTGGC TCGGG-3'; shCtr-sense, 5'-GATC
CCCTTCTCCGAACGTGTCACGTTTCAAGAGAAC GT GACACGTTCGGAGAATTTTT-3' and antisense, 5'AGCTAAAAATTCTCCGAACG TGTCACGTTCTCTTGA AACGTGACACGTTCGGAGAAGGG-3'. The shRNAs were synthesized by GenePharma (Shanghai, China). The generated plasmid encoding shROS1 or shCtr was named pRNA-H1.1-shROS1 or pRNA-H1.1-shCtr. The recombinant plasmid was transfected into BGC-823 and SGC-7901 cells using Lipofectamine 2000 (Invitrogen, Carlsbad, CA, USA). Stable clones were selected in RPMI-1640 medium containing G418 for 5 days.

\section{Western blotting}

The cells were lysed in RIPA buffer (Beyotime, Haimen, China) containing $1 \%$ protease inhibitor PMSF (Beyotime) and centrifuged at 12,000 rpm for $10 \mathrm{~min}$. The supernatant containing total proteins was aspirated and the protein concentration was determined. The total proteins were separated by SDS-PAGE (Beyotime) and then transferred onto PVDF membranes (EMD Millipore, Billerica, MA, USA). After blocking, the membranes were incubated with primary antibodies against ROS1 (1:500, Sangon Biotech, Shanghai, China), cleaved-caspase-3 (1:1000, Abcam, Cambridge Science Park, Cambridge, UK), Bcl-2 (1:400, BOSTER, Wuhan, China), Bax (1:400, BOSTER), cleaved-PARP (1:1000, Abcam), E-cadherin (1:400, BOSTER), Vimentin (1:500, BIOSS, Beijing, China), Ncadherin (1:400, BOSTER), p-PI3K (1:500, BIOSS), PI3K (1:400, BOSTER), p-Akt (1:200, Santa Cruz Biotechnology, Dallas, Texas, USA) and Akt (1:200, Santa Cruz Biotechnology) at $4^{\circ} \mathrm{C}$ overnight. After washing with TBS-Tween 20 buffer, the membranes were incubated with goat anti-rabbit IgG-HRP (Beyotime) at $37^{\circ} \mathrm{C}$ for 45 mins. The bands were developed using ECL solution (Beyotime).

\section{Quantitative real-time PCR}

RNA extraction was performed using Total RNA Extraction Kit (BioTeke, Beijing, China). Total RNAs were reverse transcribed into cDNAs and real-time PCR analysis was performed on Exicycler ${ }^{\mathrm{TM}} 96$ Thermal Block (Bioneer, Daejeon, Republic of Korea). The real-time PCR protocols were at $95^{\circ} \mathrm{C}$ for $10 \mathrm{mins}$, followed by 40 amplification cycles (at $95^{\circ} \mathrm{C}$ for $10 \mathrm{~s}$, at $60^{\circ} \mathrm{C}$ for $20 \mathrm{~s}$ and at $72^{\circ} \mathrm{C}$ for $30 \mathrm{~s}$ ). $\beta$-actin was used as an internal control. The results were analyzed using $2-\Delta \Delta \mathrm{Ct}$ method. The primers were synthesized by Sangon Biotech (Shanghai, China) and the primer sequences were: ROS1-forward, 5'-CAGTCCACGGATAGTGAAGA 
TT-3' and reverse, 5'-GGATAAGGCTGATGACC AAG-3'; $\beta$-actin-forward, 5'-CTTAGTTGCGTTACACCCTTTCTTG$3^{\prime}$ and reverse, 5'-CTGTCACCTTCACCGTTCCAGTTT-3'. Then, the transcription factor Snail, Slug and Twist were also be detected by Real-time PCR. The primer sequences are seen in Table 1.

\section{MTT assay}

After knockdown of ROS1, the cells were plated in 96-well plates and cultured in a $\mathrm{CO}_{2}$ incubator at $37^{\circ} \mathrm{C}$. Then, the cells were treated with $5 \mathrm{mg} / \mathrm{mL}$ MTT solution (SigmaAldrich, St. Louis, MO, USA) for 4 hrs at $37^{\circ} \mathrm{C}$. The supernatant was removed and DMSO was added to dissolve the formazan crystals. OD values at $490 \mathrm{~nm}$ were measured using a microplate reader (BitoTEK, Winooski, VT, USA).

\section{Colony formation assay}

The harvested cells were re-suspended in RPMI-1640 and plated in $35 \mathrm{~mm}$ petri dishes. After culturing at $37^{\circ} \mathrm{C}$, the colonies were washed with PBS and paraformaldehyde (4\%) fixed for 20 mins. After washing, the cells were stained with Wright-Giemsa solution (Jiancheng Bioengineering Institute, Nanjing, China) for 5 mins and photographed. Colonies containing more than 50 cells were counted.

\section{Cell cycle analysis by flow cytometry}

The cells were harvested $(550 \times \mathrm{g}, 5 \mathrm{mins})$ and ethanol fixed at $4^{\circ} \mathrm{C}$ for $2 \mathrm{hrs}$. Then, the ethanol-fixed cells were washed and stained with $25 \mu \mathrm{l}$ propidium iodide (PI) (Beyotime) for 30 mins at $37^{\circ} \mathrm{C}$. Cell cycle distribution was analyzed by BD flow cytometer (Franklin Lakes, NJ, USA).

\section{Cell apoptosis by flow cytometry}

The cell culture was centrifuged at $309 \times \mathrm{g}$ for 5 mins. After washing with PBS, the cells were re-suspended in Binding buffer. The cells were gently mixed with $5 \mu \mathrm{L}$ Annexin V-FITC and $10 \mu \mathrm{L}$ PI (KeyGEN, Nanjing, China) for 15 mins at room temperature. Cell apoptosis was analyzed by BD flow cytometer (Franklin Lakes, NJ, USA).

\section{Wound healing assay}

After transfection shROS1, the supernatant was removed using pipettes and the monolayer was wounded by $200 \mu \mathrm{L}$ sterile pipette tips. The monolayer was washed with serum-free medium and photographed $(0 \mathrm{hr})$. Then, the cells were cultured in serum-free medium for 12 and 24 hrs to test the migratory capabilities of shRNA-transfected gastric cancer cells.

\section{Transwell invasion assay}

The cells $\left(2 \times 10^{4}\right.$ cells $)$ were added into the upper chamber of the Matrigel-coated Corning Incorporated Transwell chamber (Corning, NY, USA) and RPMI-1640 containing $30 \%$ FBS was added into the lower chamber. After culturing for $24 \mathrm{hrs}$, the cells were fixed and stained with $0.5 \%$ crystal violet. The cells in five random fields were counted under an inverted microscope.

\section{Statistical analysis}

Data are presented as mean $\pm \mathrm{SD}$ and analyzed by oneway ANOVA and Bonferroni's multiple comparison test using GraphPad Prism, version 5.0 (GraphPad Software Inc., La Jolla, CA, USA). The differences in clinicopathological parameters between gastric cancer patients with high or low ROS1 expression were compared using the Chi-squared test. The difference between the survival curves was analyzed by Log-rank test. A value of $P<0.05$ was considered a statistically significant difference.

Table I Primer sequences

\begin{tabular}{|l|l|l|l|l|}
\hline Name & Sequences & Primer length & Tm & Products length \\
\hline Twist F & GGAGTCCGCAGTCTTACGA & 19 & 55.7 & 162 \\
Twist R & CCAGCTTGAGGGTCTGAATC & 20 & 56.9 & \\
Slug-F & GTTGCCATTGTTGAACTAAAGCC & 23 & 60.9 & 168 \\
Slug-R & CTCCTCCCCCAAGGCACATACT & 22 & 64.2 & \\
Snail-F & GCCCCACAGGACTTTGATGA & 20 & 60.4 & 214 \\
Snail-R & AGTGAGTCTGTCAGCCTTTGTC & 22 & 55.9 & \\
$\beta$-actin F & CTTAGTTGCGTTACACCCTTTCTTG & 25 & 62 & 156 \\
$\beta$-actin R & CTGTCACCTTCACCGTTCCAGTTT & 24 & 64.4 & \\
\hline
\end{tabular}




\section{Results}

Analysis of ROSI expression, clinicopathologic factors and prognosis of gastric cancer using TCGA database

To validate the mRNA expression of ROS1 and clinicopathologic factors of gastric cancer, the data was obtained from TCGA (https://portal.gdc.cancer.gov/). The ROS1 mRNA expression in gastric cancers was significantly elevated compared to 35 normal mucosa samples $(P<0.0001$, Figure 1A). The ROS1 mRNA expression in patients with gastric cancer showed four significantly relative relationship with depth of invasion, lymph node metastasis, distant metastasis and TNM staging $(P<0.0001$, Table 2$)$. The $P$-value of tumor grade is 0.014 , but it may be because the samples were different. Its $P$-value was larger than others. Additionally, results revealed that the median survival time in ROS1-high group was 22.170 \pm 2.823 , shorter than that in ROS1-low group $(55.390 \pm 11.846)$. Higher ROS1 mRNA expression was associated with worse prognosis compared with the low-expression $(P=0.003$, Figure 1B). These data suggested that ROS1 might act as an oncogenic gene in gastric cancer and predict poor prognosis.
A

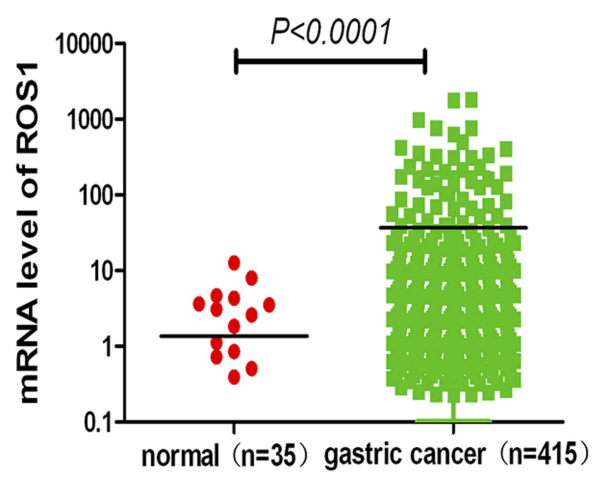

C
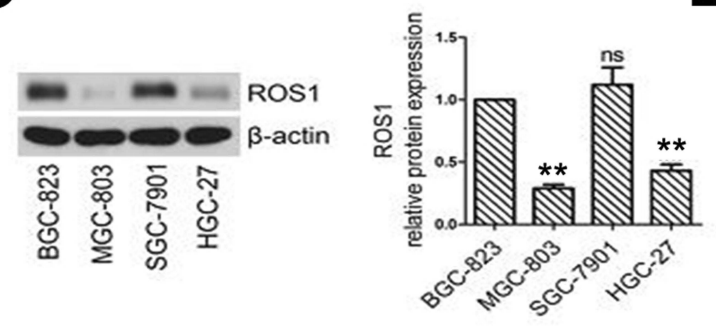

E
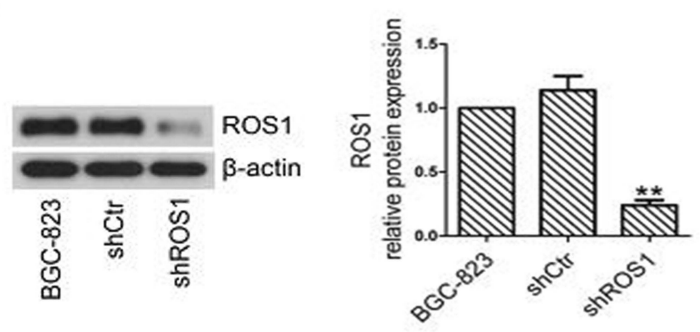

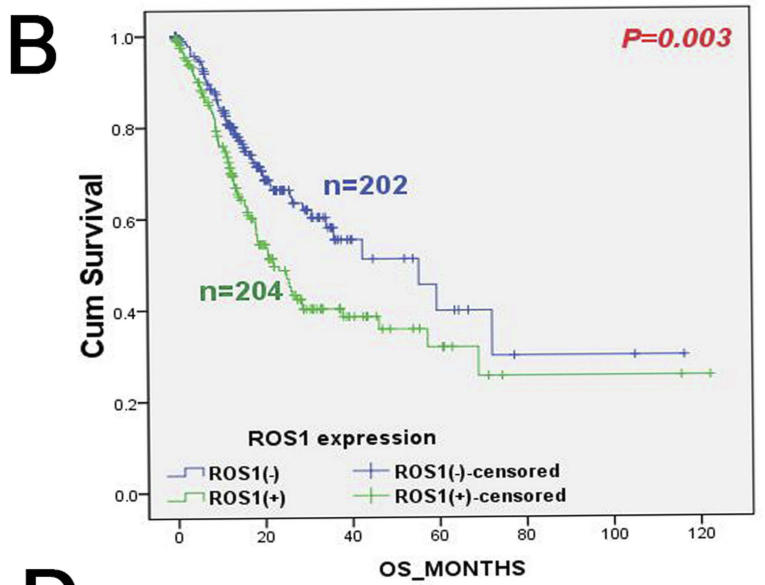

D
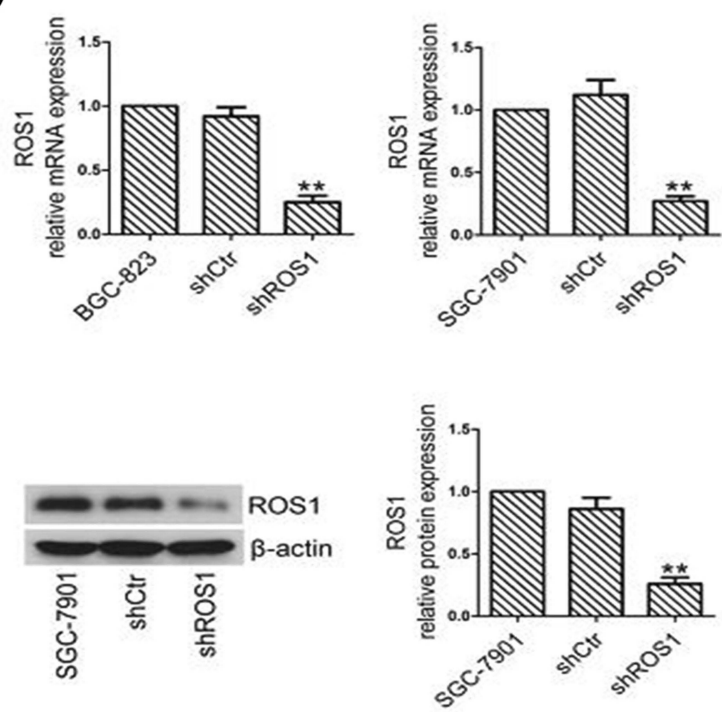

Figure I ROSI expression in gastric cancer tissue and gastric cancer cell lines. (A) The ROSI mRNA expression was significantly elevated in gastric cancer compared to normal mucosa samples according to the data from TCGA $(P<0.0001)$. (B) Patients with high expression of ROSI predicted a worse prognosis than that with low-expressed ROSI $(P=0.003)$. (C) Total proteins were extracted from BGC-823, MGC-803, SGC-790I and HGC-27 cells. The expression of ROSI was determined by Western blotting. (D) BGC-823 and SGC-790I cells were transfected with shROSI or shCtr. Real-time PCR was performed to examine ROSI expression in shRNA-transfected cells. The results were normalized to internal control ( $\beta$-actin). (E) After shRNA transfection, we measured the changes of ROSI expression in BGC-823 and SGC-790I cells by Western blotting. The results were shown as mean \pm SD. $* * P<0.01$ versus the shCtr group.

Abbreviation: ns, not significant. 
Table 2 Correlation between ROSI expression and clinicopathological features in gastric cancer

\begin{tabular}{|c|c|c|c|c|c|}
\hline \multirow[t]{2}{*}{ Variable } & \multirow[t]{2}{*}{$\mathbf{n}$} & \multicolumn{2}{|c|}{ ROSI expression } & \multirow[t]{2}{*}{$\chi^{2}$} & \multirow[t]{2}{*}{$P$-value } \\
\hline & & Low & High, n (\%) & & \\
\hline Age (year) & 409 & & & 2.093 & 0.148 \\
\hline$\leq 60$ & 132 & 59 & $73(55.3)$ & & \\
\hline$>60$ & 277 & 145 & $132(47.65)$ & & \\
\hline Gender & 414 & & & 0.095 & 0.758 \\
\hline Male & 267 & 132 & $135(50.56)$ & & \\
\hline Female & 147 & 75 & $72(48.398)$ & & \\
\hline Grade & 405 & & & 10.566 & 0.014 \\
\hline GI & 12 & 8 & $4(33.33)$ & & \\
\hline G2 & 147 & 87 & $60(40.82)$ & & \\
\hline G3 & 246 & 107 & $139(56.50)$ & & \\
\hline Depth of invasion & 405 & & & 112.960 & 0.000 \\
\hline TI & 22 & 22 & $0(0.00)$ & & \\
\hline $\mathrm{T} 2$ & 87 & 74 & $13(14.94)$ & & \\
\hline T3 & 181 & 81 & $100(55.25)$ & & \\
\hline $\mathrm{T} 4$ & 115 & 21 & $94(81.74)$ & & \\
\hline Lymph node metastasis & 395 & & & 212.770 & 0.000 \\
\hline No & 122 & 116 & $6(4.92)$ & & \\
\hline $\mathrm{NI}$ & 112 & 59 & $53(47.32)$ & & \\
\hline N2 & 79 & 13 & $66(83.54)$ & & \\
\hline N3 & 82 & I & 81 (98.78) & & \\
\hline Distant metastasis & 384 & & & 24.312 & 0.000 \\
\hline Mo & 367 & 194 & $173(47.14)$ & & \\
\hline MI & 27 & I & $26(96.30)$ & & \\
\hline TNM staging & 389 & & & 377.164 & 0.000 \\
\hline I & 56 & 56 & $0(0.00)$ & & \\
\hline II & 123 & 123 & $0(0.00)$ & & \\
\hline III & 169 & 3 & 166 (98.22) & & \\
\hline IV & $4 \mid$ & 0 & $41(100.00)$ & & \\
\hline
\end{tabular}

\section{Expression of ROSI in human gastric} cancer cells

We measured the expression of ROS1 in four gastric cancer cell lines (BGC-823, MGC-803, SGC-7901 and HGC-27) using Western blotting. The results showed that BGC-823 and SGC-7901 cells expressed higher levels of ROS1 than the other two cell lines (MGC-803 and HGC27) (Figure 1C).

\section{ROSI knockdown inhibits cell proliferation and colony formation in gastric cancer cells}

To evaluate the function of ROS1 in human gastric cancer cells, we transfected BGC-823 and SGC-7901 cells with shROS1 or shCtr and examined ROS1 expression using quantitative real-time PCR and Western blotting. The results showed that ROS1 expression was significantly downregulated in both BGC-823 and SGC-7901 cells after shROS1 transfection (Figure 1D and $\mathrm{E}$ ). We then measured cell viabilities for 5 consecutive days using MTT assay. The results showed that the viable cell numbers in the $\operatorname{sh} R O S 1$ group were lower than those in the shCtr group on day 2, 3, 4 and 5 (Figure 2A). Colony formation assay showed that clonogenic growth ability of the cells that transfected with shROS1 was reduced compared with that of shCtr-transfected cells (Figure 2B). Cell cycle progression was analyzed by flow cytometry. We found that the cell percentages of G1 phase and G2 phase in the shROS1 

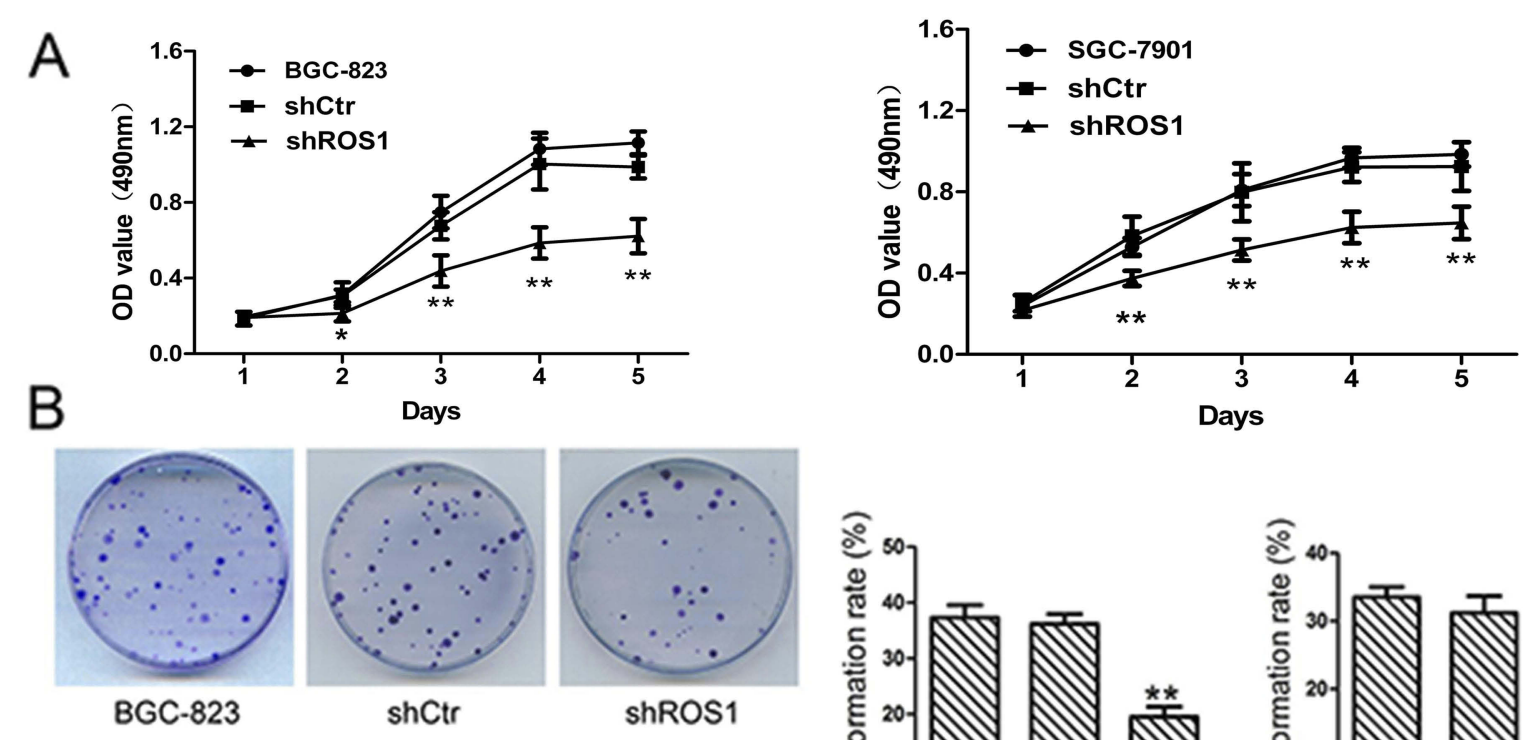

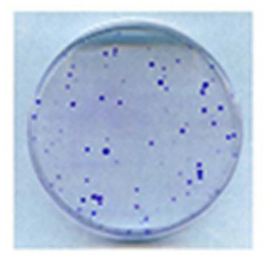

SGC-7901

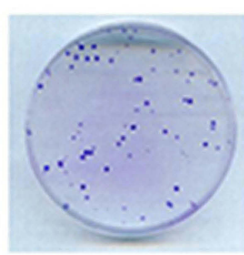

shCtr
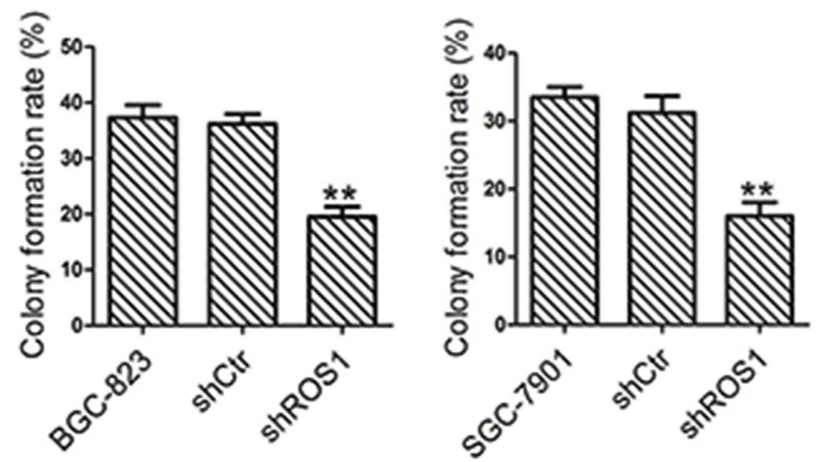

ShROS1

C
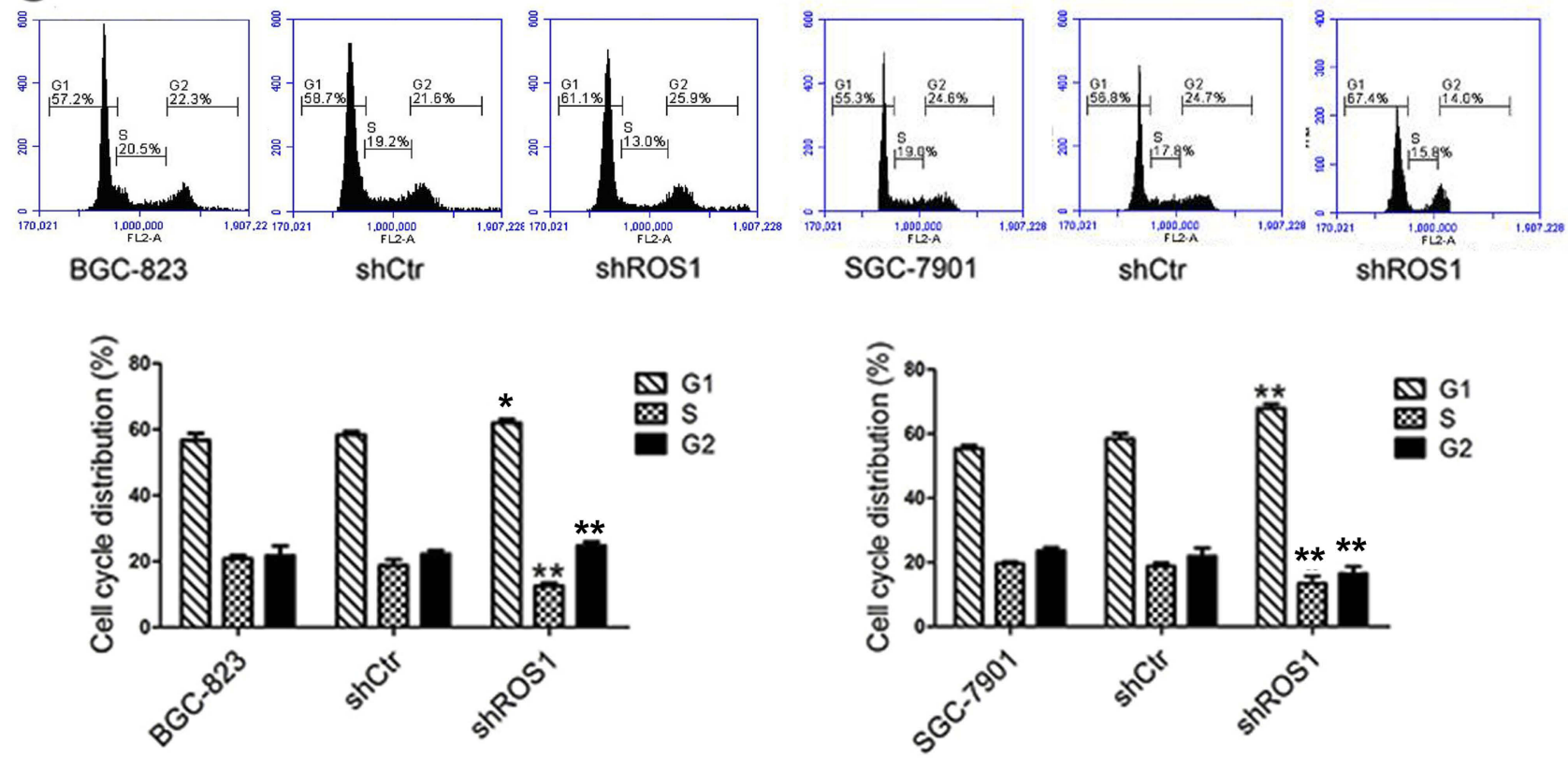

Figure 2 ROSI knockdown reduced cell viability and suppresses colony formation of gastric cancer cells. (A) Cell viability was examined by MTT assay on day I, 2, 3, 4 and 5 . (B) Three groups of cells were seeded in $35 \mathrm{~mm}$ petri dishes for assessment the colony formation capacity of BGC-823 and SGC-790I cells. (C) The cells were subjected to flow cytometric analysis for assessment of cell cycle progression. The results were shown as mean $\pm \mathrm{SD}$. $* P<0.05$, $* * P<0.0$ I versus the shCtr group.

group in BGC-823 cells were higher than those in the shCtr group. The fraction of shROS1-transfected BGC823 cells in the $\mathrm{S}$ phase was significantly lower than that of the shCtr-transfected cells. In SGC-7901 cells, the cell percentage of G1 phase was markedly increased while the cell percentages of $\mathrm{S}$ and $\mathrm{G} 2$ phases were decreased in the shROS1 group compared with those in the shCtr group (Figure 2C). 


\section{ROSI knockdown promotes cell apoptosis in gastric cancer cells}

We further investigated the effect of ROS1 knockdown on cell apoptosis by flow cytometry. Flow cytometric analyses showed that the ROS1 knockdown significantly increased the cell apoptosis rate when compared with the shCtr group (Figure 3A). Western blotting was performed to quantify the expression of cleaved-caspase-3, cleavedPARP, Bcl-2 and Bax. We found that shROS1-transfected cells expressed increased expression levels of cleavedcaspase-3, cleaved-PARP and Bax and a decreased expression level of Bcl-2 compared with the shCtr-transfected cells (Figure 3B).

\section{ROSI knockdown inhibits cell migration, invasion and cell EMT in gastric cancer cells}

The migration and invasion capabilities of shRNA-transfected gastric cancer cells were examined by wound healing and Transwell assays. As shown in Figure 4, ROSI knockdown inhibited the migration and invasion of both BGC-823 and SGC-7901 cells as compared with the shCtr group. We then investigated whether ROS1 knockdown influenced EMT progression in gastric cancer in vitro. We found that transfection of shROS1 into BGC-823 and SGC-7901 cells resulted in upregulated levels of E-cadherin and downregulated levels of Vimentin and N-cadherin (Figure 5). At the same time, gene expression of the transcription factor Twist Snail and Slug associated with EMT was also downregulated when ROS1 was knocked down in BGC-823 and SGC-7901 cells (Figure 6).

\section{ROSI knockdown inhibits PI3K/Akt signaling pathway activation}

To explore whether PI3K/Akt signaling pathway was involved in the inhibitory effects of ROS1 knockdown on clonogenic growth and metastasis of gastric cancer cells in vitro, we examined p-PI3K, PI3K, p-Akt and Akt protein levels by Western blotting and then calculated the ratios of $\mathrm{p}-\mathrm{PI} 3 \mathrm{~K} / \mathrm{PI} 3 \mathrm{~K}$ and $\mathrm{p}$-Akt/Akt. The results showed that shRNA-mediated knockdown of ROS1 reduced the levels of p-PI3K and p-Akt in both BGC-823 and SGC-7901 cells (Figure 7).

\section{Discussion}

ROS1 rearrangement has been reported in multiple cancers, such as gastric adenocarcinoma, non-small cell lung cancer (NSCLC), ovarian cancer, glioblastoma and colorectal cancer. ${ }^{19}$ However, no study has clarified the role of ROS1 in gastric cancer. In the present study, TCGA database was applied to analyze the mRNA expression of ROS1 in gastric cancer. The results showed that $R O S 1$ was overexpressed in gastric cancer compared to normal mucosa samples. Higher level of ROS1 was related to depth of invasion, lymph node metastasis, distant metastasis and TNM staging. In addition, higher expression predicted worse prognosis of patients with gastric cancer. Then, we knocked down ROS1 expression in gastric cancer BGC-823 and SGC-7901 cells. Davies $\mathrm{KD}$ et al have demonstrated that ROS1 inhibition mediated by crizotinib and NVP-TAE684 (both are ALK inhibitors with activities against ROS1) inhibits HCC78 cell proliferation. ${ }^{20}$ We found that ROS1 knockdown mediated by specific shRNA transfection significantly reduced cell viability and inhibited colony formation of gastric cancer cells (BGC-823 and SGC7901). Deng $G$ et al have observed similar results in intrahepatic cholangiocarcinoma cells, ${ }^{18}$ which are consistent with our studies. Cell cycle is a highly ordered process that tightly regulated by multiple cell cyclerelated regulators. ${ }^{21}$ Cell cycle dysregulation is the hallmark of cancer. ${ }^{22}$ Cell cycle arrest can lead to inhibition of cell growth. ${ }^{23}$ Therefore, in our study, we further confirmed whether cell growth inhibition in gastric cancer cells was associated with cell cycle arrest. Flow cytometric analysis showed that ROS1 knockdown arrested the cell cycle at G1 phase. The observations indicate that $R O S 1$ knockdown may inhibit proliferation and clonogenic growth of gastric cancer cells in vitro by inducing cell cycle arrest.

Apoptosis, which is also called Type 1 programmed cell death, is characterized by shrinkage of cells, DNA fragmentation, nuclear condensation and the formation of apoptotic bodies. $^{24,25}$ Flow cytometric analysis showed that knockdown of ROS1 in gastric cancer cells significantly induced cell apoptosis compared with the shCtr group. Caspase, a family of cysteine proteases, regulates the initiation and execution of apoptosis. ${ }^{26}$ Poly ADPribose protein (PARP) is the substrate of caspase-3 (a crucial executioner in apoptosis) and can be cleaved into two fragments during apoptosis. ${ }^{27}$ Our results showed that ROS1 knockdown markedly increased cleaved-caspase-3 and cleaved-PARP levels in gastric cancer cells. Antiapoptotic protein $\mathrm{Bcl}-2$ and pro-apoptotic protein Bax are two members of Bcl-2 family. ${ }^{28}$ Bax and Bcl-2 imbalance is key to the regulation of cell apoptosis. ${ }^{29}$ Next, we 
A

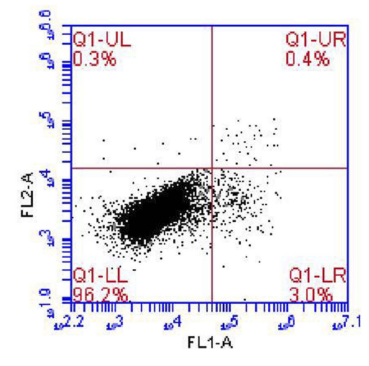

BGC-823

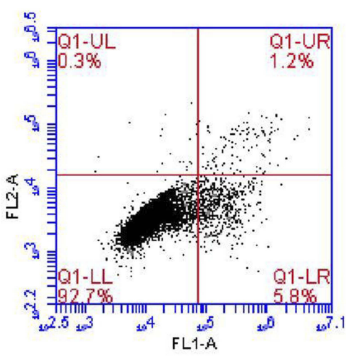

SGC-7901

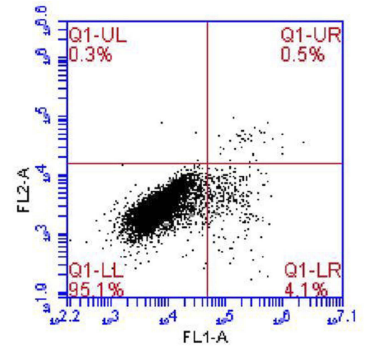

shCtr

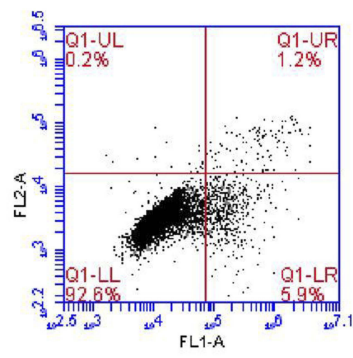

shCtr

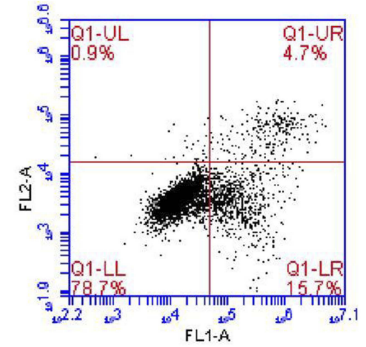

shROS1

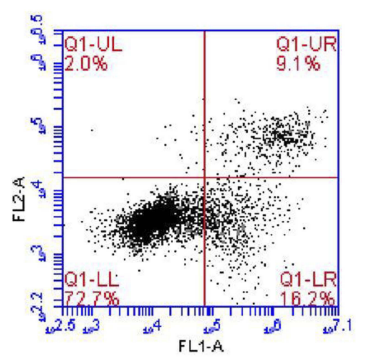

shROS1
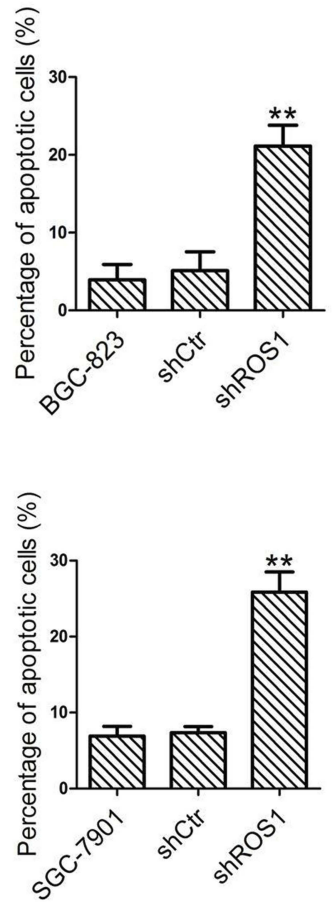

B
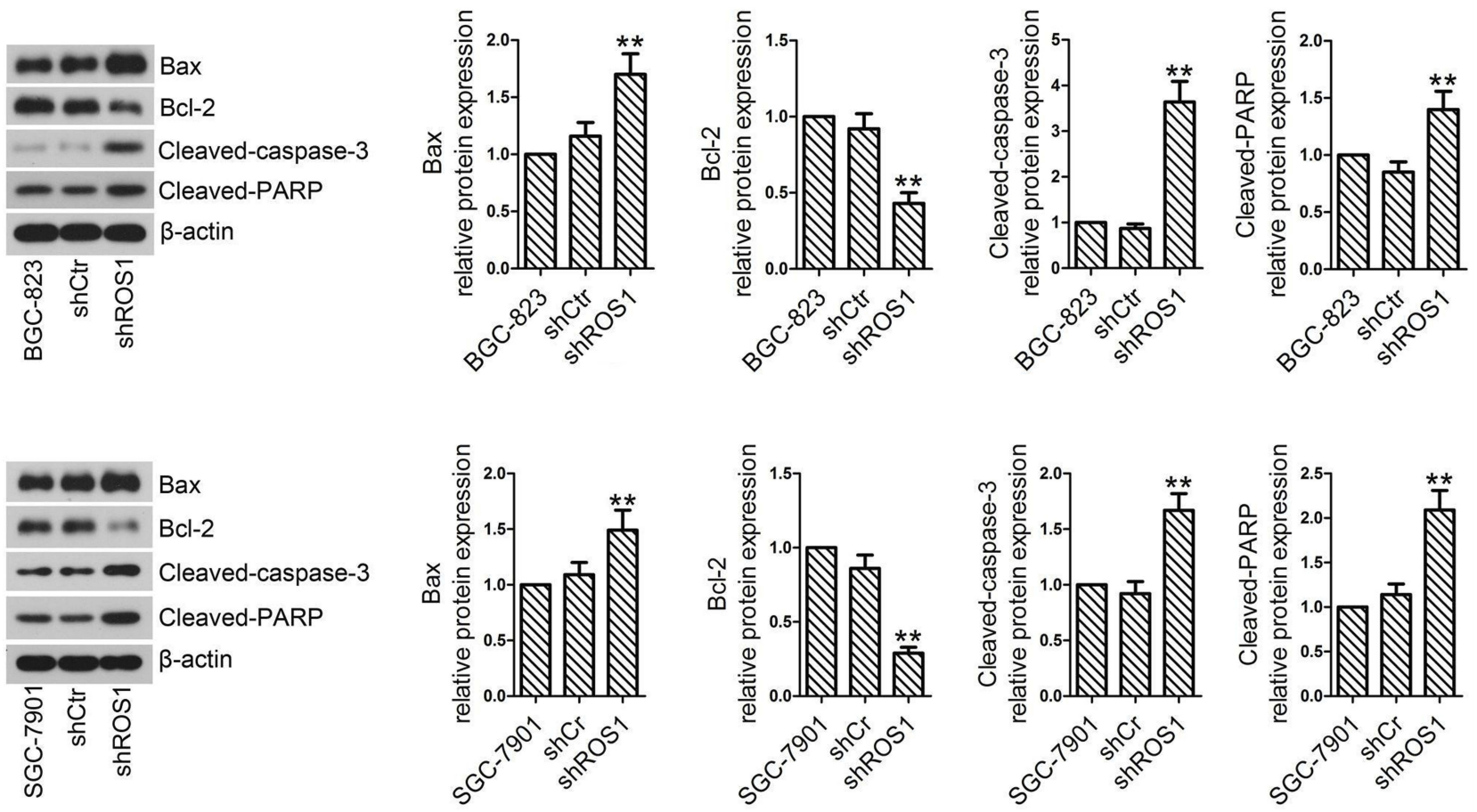

Figure 3 ROSI knockdown promotes apoptosis of gastric cancer cells. (A) Cell apoptosis rate of gastric cancer cells transfected with shROSI or shCtr was determined by Annexin V/PI staining assay. (B) Protein levels of cleaved-Caspase-3, cleaved-PARP, Bcl-2 and Bax were quantified by Western blotting. The results were shown as mean \pm SD. $* * P<0.01$ versus the shCtr group.

measured the expression levels of Bax and Bcl-2. Western blotting results showed that a significant up-regulation of Bax level was detected in cells after ROS1 knockdown, whereas Bcl-2 was down-regulated. Our observations suggest that ROSI knockdown may promote gastric cancer cell apoptosis by inducing the imbalance between Bax and Bcl-2 and activating caspase- 3 and its downstream substrate PARP. 

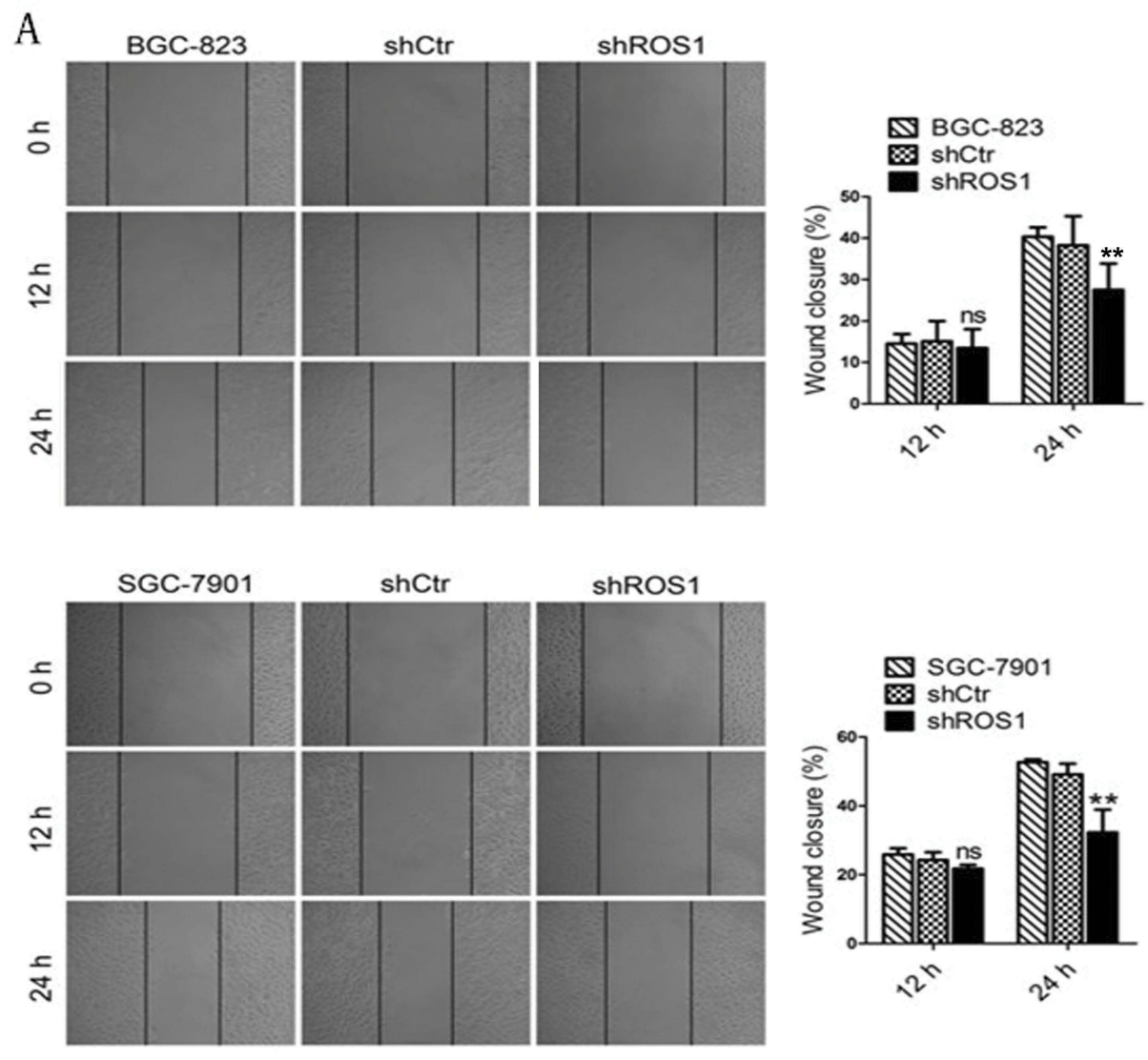

B

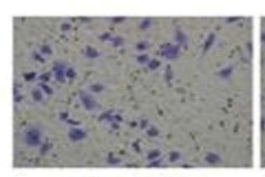

BGC-823

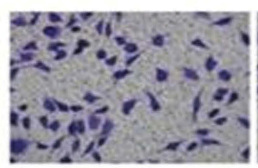

SGC-7901

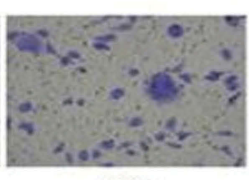

shCtr

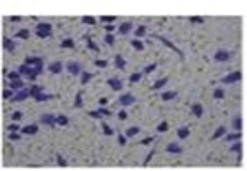

shCtr

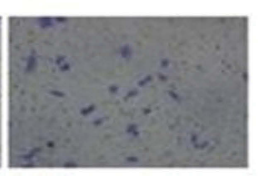

shROS1

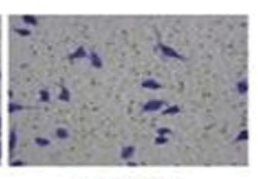

shROS1
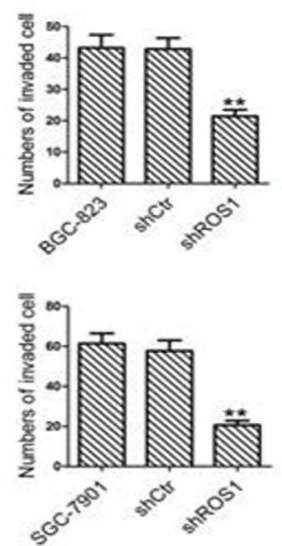

Figure 4 (A) ROSI knockdown suppresses migration of gastric cancer cells. Migration abilities of gastric cancer cells transfected with shRNA were determined by wound healing assay. (B) Invasion abilities of the cells in the three groups were assessed by Transwell assay. The results were shown as mean \pm SD. $* * P<0.01$ versus the shCtr group. Abbreviation: ns, not significant.

Cancer metastasis, which involves many processes, such as cell migration and invasion, intravasation, metastasis through blood and lymph, extravasation and tumor formation in new tissues or organs, is the leading cause of treatment failure in cancer patients. ${ }^{30,31}$ Previous evidences have shown that the invasion of breast cancer cells and lung cancer cells is inhibited by miRNA-33a and curcumin, accompanied by the decrease of ROS1. ${ }^{32,33}$ Deng $\mathrm{G}$ et al have demonstrated that ROS1 shRNA transfection inhibits the migration and invasion of intrahepatic cholangiocarcinoma cells. ${ }^{18}$ Consistently, we found that ROS1 knockdown significantly reduced the migratory and invasive capabilities of gastric cancer cells. EMT has been demonstrated to be a 

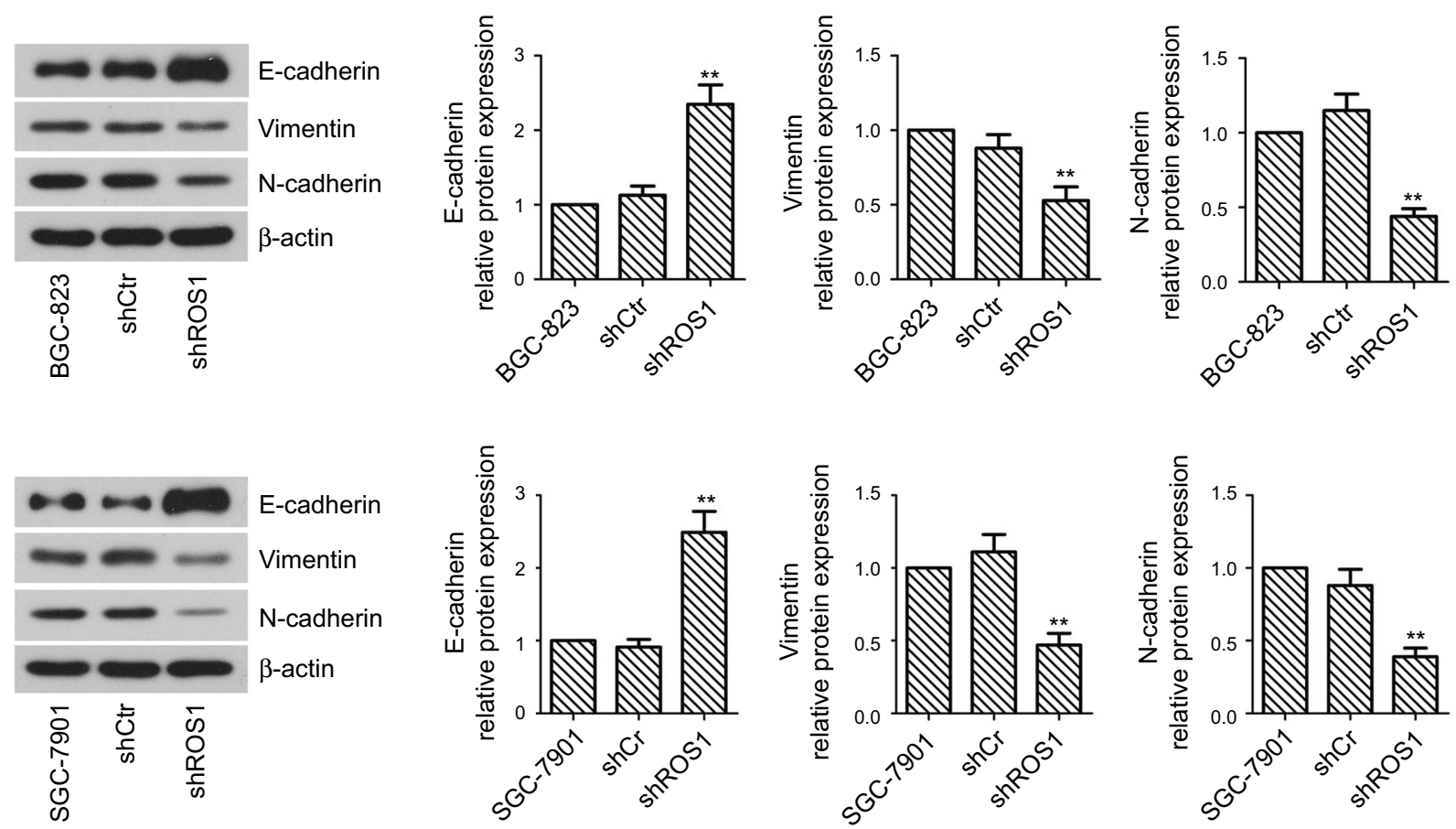

Figure 5 ROSI knockdown suppresses invasion and EMT of gastric cancer cells. The cells in the three groups were subjected to total protein extraction. The expression of EMTrelated markers, including E-cadherin, $\mathrm{N}$-cadherin and Vimentin, was measured by Western blotting. The results were shown as mean $\pm \mathrm{SD}$. $* * \mathrm{P}<0.01$ versus the shCtr group.

major cause of cell migration and invasion. EMT is a process during which cancer cells lose epithelial characteristics and acquire mesenchymal features, which is accompanied by the downregulation of E-cadherin and the upregulation of N-cadherin, Snail and Vimentin. ${ }^{34}$ EMT has been demonstrated to be a crucial step in the metastasis of cancer. ${ }^{35}$ Our results showed that knockdown of ROS1 greatly increased E-cadherin expression and decreased N-cadherin and Vimentin levels in gastric cancer cells. Twist, Slug and Snail were all upstream transcription factor of EMT.

Twist is a member of the basic helix loop helix transcription factor (bHLH) family of transcription factors, including Twist 1 and Twist2. It has the ability to regulate embryonic tissue development and the ability to migrate cells during embryonic development. Studies have shown that in the cells that expressed Twist, E-cadherin and beta-catenin and other adhesion protein expression was reduced, at the same time invasion ability of the cells also declined. ${ }^{36}$ Snail gene is a transcription factor with zinc finger structure, which is the first transcription factor to induce EMT. During embryonic development, Snail can bind to E-cadherin on the proximal promoter of E-box, inhibit the transcription of E-cadherin gene, decrease the level of E-cadherin protein in cells and promote the process of cell EMT. Studies have shown that ectopic expression of Snail in epithelial cells of the phenotype of fibroblasts and the ability to obtain tumor invasion. ${ }^{37}$ Slug, also known as Snail2, is another transcription factor in the Snail family. It is the sign of the migration ability of mesoderm and neural crest cells in embryonic development. Like Snail, it is also combined with E-cadherin on the proximal promoter of E-box to inhibit the transcription of E-cadherin gene, decrease the level of intracellular E-cadherin protein and promote the process of EMT cell. ${ }^{38}$ TGF can upregulate the expression of Snail and Slug, and promote the occurrence and development of EMT. ${ }^{39}$ In this study, the expression of Twist, Slug and Snail in gastric cancer cells, was all downregulated after the ROS1 was knocked down. So ROS1 can induce cancer cells EMT through activating Twist, Slug and Snail. All these results suggest that ROS1 knockdown may impair the migration and invasion of gastric cancer cells by reversing EMT.

Accumulating studies have reported that PI3K/Akt signaling pathway activation plays a critical role in cancer progression by regulating the malignant phenotypes of cancer cells, including gastric cancer. ${ }^{40-42}$ Moreover, inhibition of PI3K/Akt signaling pathway has been used as a therapeutic strategy to treat gastric 

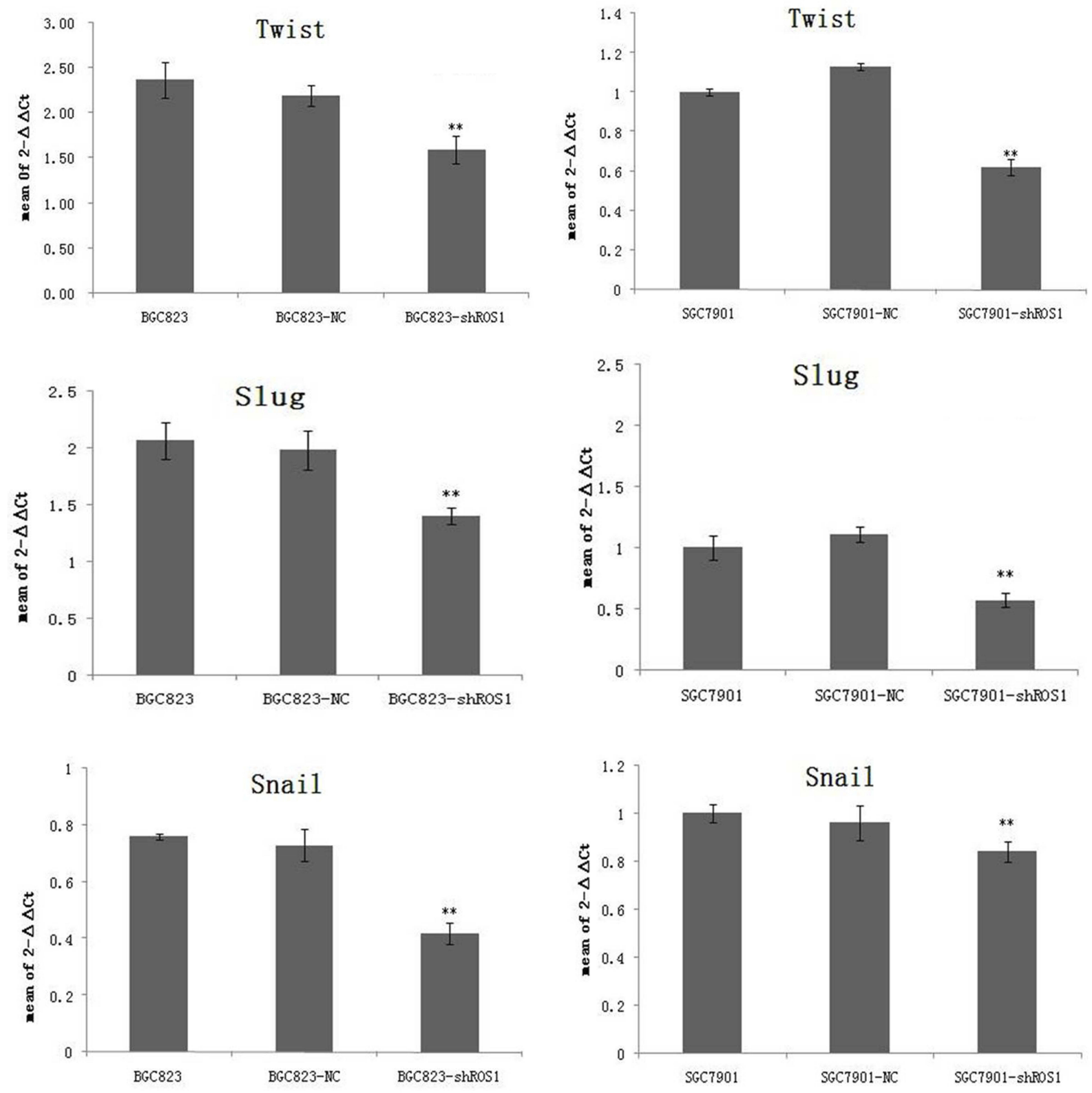

Figure 6 ROSI knockdown suppresses expression of transcription factor Twist, Slug and Snail. The results were shown as mean \pm SD. $* * P<0.01$ versus the shCtr group.

cancer patients. ${ }^{43}$ Evidences of ROS1 targeted PI3K/Akt signaling pathway existed in some aspects. ROS1 was reported to be involved in BMSC fate switching between osteogenesis and adipogenesis, mediated via PI3K/AKT/mTORC1 signaling. ${ }^{44}$ Silencing of ROS1 gene could sensitize mouse breast cancer cells both in vitro and in vivo, preventing activation of the survival pathway protein AKT1. ${ }^{17}$ ROS1 also involved in cell proliferation, colony formation, cell cycle progression, migration and invasion of intrahepatic cholangiocarcinoma through AKT signaling pathway. ${ }^{18}$ Our results showed that the levels of p-PI3K and p-Akt downgraded in both BGC-823 and SGC-7901 cells, which indicated PI3K/Akt signaling pathway was significantly inhibited after ROS1 knockdown in gastric cancer cells. Above evidences may suggest that ROS1 knockdown may inhibit the development of gastric cancer via the PI3K/Akt signaling pathway.

\section{Conclusion}

Taken together, our results demonstrated for the first time that ROS1 was upegulated in gastric cancer. ROS1 

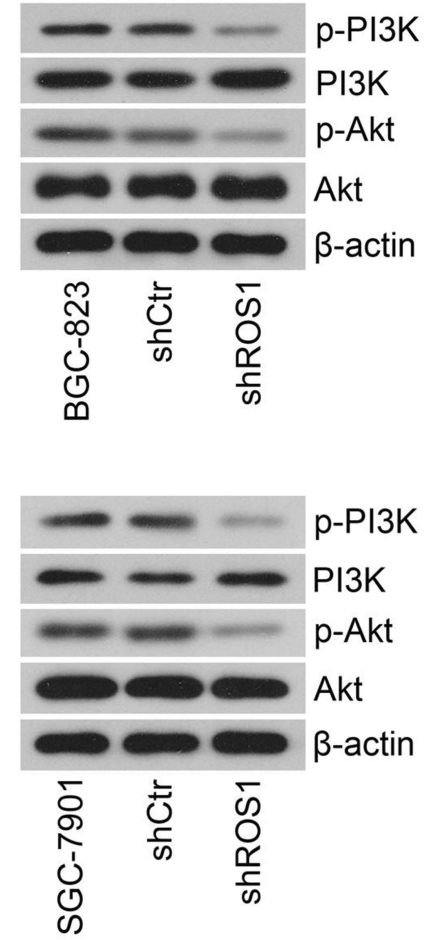
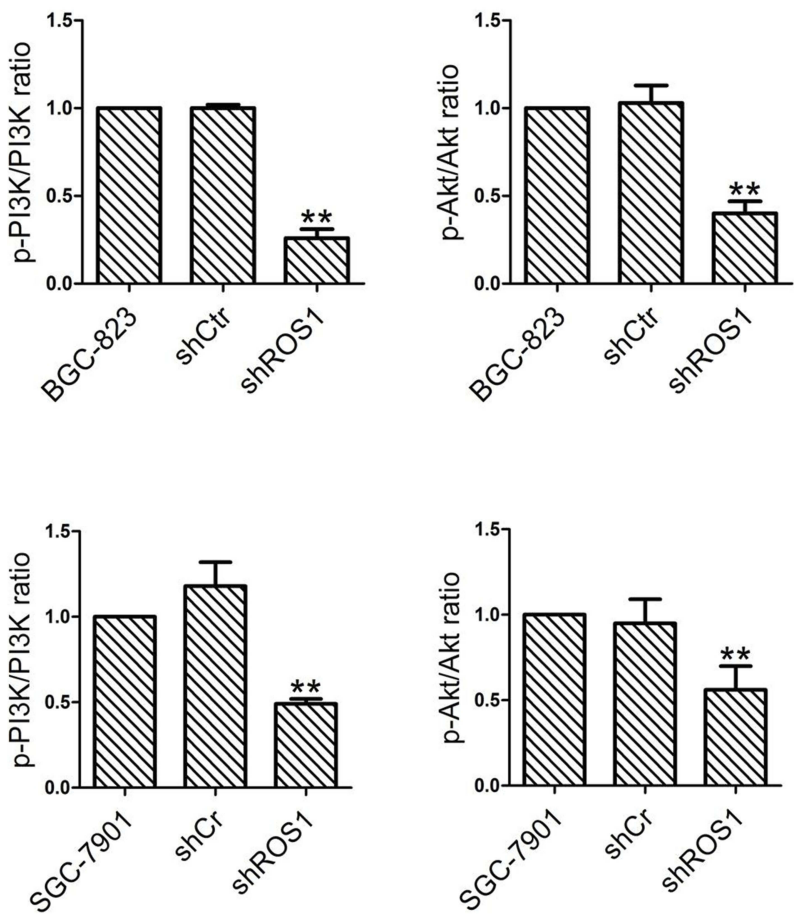

Figure 7 The levels of $\mathrm{PI} 3 \mathrm{~K}, \mathrm{p}-\mathrm{PI} 3 \mathrm{~K}$, Akt and $\mathrm{p}$-Akt were quantified by Western blotting. The ratios of $\mathrm{p}-\mathrm{PI} 3 \mathrm{~K} / \mathrm{PI} 3 \mathrm{~K}$ and $\mathrm{p}-\mathrm{Akt} / \mathrm{Akt}$ were calculated. The results were shown as mean $\pm S D$. $* * P<0.01$ versus the shCtr group.

knockdown significantly inhibited cell growth, induced cell apoptosis, inhibited EMT and metastasis in gastric cancer by inhibiting the PI3K/Akt signaling pathway. Our study provides a new therapeutic strategy for the treatment of gastric cancer.

\section{Acknowledgment}

This study was supported by Supporting Project for Climbing Scholars in Liaoning Provincial Universities, China (2009).

\section{Author contributions}

The study was conceived and designed by Yan Xin. The experiments and manuscript were performed and prepared by Jingjing Qiao and Dan Sun. Wenhui Li analyzed the data. Man Li supervised the study progression. All authors contributed to data analysis, drafting and revising the article, gave final approval of the version to be published, and agree to be accountable for all aspects of the work.

\section{Disclosure}

The authors report no conflicts of interest in this work.

\section{References}

1. Khan SA, Amnekar R, Khade B, et al. p38-MAPK/MSK1-mediated overexpression of histone $\mathrm{H} 3$ serine 10 phosphorylation defines distance-dependent prognostic value of negative resection margin in gastric cancer. Clin Epigenetics. 2016;8:88. doi:10.1186/s13148-016-0255-9

2. Matsusaka K, Ushiku T, Urabe M, et al. Coupling CDH17 and CLDN18 markers for comprehensive membrane-targeted detection of human gastric cancer. Oncotarget. 2016;7(39):64168-64181. doi:10.18632/oncotarget.11638

3. Jiang WL, Zhang PF, Li GF, et al. Oct-4is associated with gastric cancer progression and prognosis. Onco Targets Ther. 2016;9:517522. doi: $10.2147 / \mathrm{OTT}$. S90031

4. Wang L, Chang Y, Xu J, et al. Predictive significance of serum level of vascular endothelial growth factor in gastric cancer patients. Biomed Res Int. 2016;2016:8103019.

5. Hu Q, Peng J, Liu W, et al. Lin28B is a novel prognostic marker in gastric adenocarcinoma. Int J Clin Exp Pathol. 2014;7(8):5083-5092.

6. Sun W, Yan L. Gastric cancer: current and evolving treatment landscape. Chin J Cancer. 2016;35(1):83. doi:10.1186/s40880-016-0147-6

7. Chen CN, Chang CC, Lai HS, et al. Connective tissue growth factor inhibits gastric cancer peritoneal metastasis by blocking integrin alpha3beta1-dependent adhesion. Gastric Cancer. 2015;18(3):504515. doi:10.1007/s10120-014-0400-0

8. Tsukamoto T, Togano S, Edagawa E, et al. A case of gastric neuroendocrine carcinoma with bulky lymph node metastases, solitary liver metastasis, and left adrenal metastasis curatively resected after chemotherapy. Gan To Kagaku Ryoho. 2019;46(1):103-105.

9. Scheffler M, Schultheis A, Teixido C, et al. ROS1 rearrangements in lung adenocarcinoma: prognostic impact, therapeutic options and genetic variability. Oncotarget. 2015;6(12):10577-10585. doi:10.18632/ oncotarget.3387 
10. Wu J, Lin Y, He X, et al. Comparison of detection methods and follow-up study on the tyrosine kinase inhibitors therapy in non-small cell lung cancer patients with ROS1 usion rearrangement. BMC Cancer. 2016;16:599. doi:10.1186/s12885-016-2582-9

11. Fu S, Liang Y, Lin YB, et al. The frequency and clinical implication of ROS1 and RET rearrangements in resected stage IIIA-N2 nonsmall cell lung cancer patients. PloS One. 2015;10(4):e0124354. doi:10.1371/journal.pone.0124354

12. Lim SM, Yoo JE, Lim KH, et al. Rare incidence of ROS1 rearrangement in cholangiocarcinoma. Cancer Res Treat. 2017;49(1):185-192. doi: $10.4143 /$ crt.2015.497

13. Lee KH, Lee KB, Kim TY, et al. Clinical and pathological significance of ROS1 expression in intrahepatic cholangiocarcinoma. BMC Cancer. 2015;15:721. doi:10.1186/s12885-015-1584-3

14. Ogawa H, Tanaka Y, Tachihara M, et al. ROS1-rearranged high-PD-L1expressing lung adenocarcinoma manifesting as mediastinal tumor: a case report. Oncol Lett. 2019;17(1):488-491. doi:10.3892/ol.2018.9622

15. Mohan A, Harris K, Bowling MR, et al. Therapeutic bronchoscopy in the era of genotype directed lung cancer management. J Thorac Dis. 2018;10(11):6298-6309. doi:10.21037/jtd.2018.08.14

16. Bubendorf L, Buttner R, Al-Dayel F, et al. Testing for ROS1 in nonsmall cell lung cancer: a review with recommendations. Virchows Arch. 2016;469(5):489-501. doi:10.1007/s00428-016-2000-3

17. Tiash S, Chua MJ, Chowdhury EH. Knockdown of ROS1 gene sensitizes breast tumor growth to doxorubicin in a syngeneic mouse model. Int J Oncol. 2016;48(6):2359-2366. doi:10.3892/ijo.2016.3452

18. Deng G, Hu C, Zhu L, et al. Downregulation of ROS-FIG inhibits cell proliferation, colony-formation, cell cycle progression, migration and invasion, while inducing apoptosis in intrahepatic cholangiocarcinoma cells. Int J Mol Med. 2014;34(3):661-668. doi:10.3892/ijmm.2014.1823

19. Davies KD, Doebele RC. Molecular pathways: ROS1 fusion proteins in cancer. Clin Cancer Res. 2013;19(15):4040-4045. doi:10.1158/ 1078-0432.CCR-12-2851

20. Davies KD, Le AT, Theodoro MF, et al. Identifying and targeting ROS1 gene fusions in non-small cell lung cancer. Clin Cancer Res. 2012;18(17):4570-4579. doi:10.1158/1078-0432.CCR-12-0550

21. Hsieh YH, Lee CH, Chen HY, et al. Induction of cell cycle arrest, DNA damage, and apoptosis by nimbolide in human renal cell carcinoma cells. Tumour Biol. 2015;36(10):7539-7547. doi:10.1007/s13277-015-3477-0

22. Tian C, Ding P, Yuan Z, et al. A novel dual EGFR/HER2 inhibitor KU004 induces cell cycle arrest and apoptosis in HER2-overexpressing cancer cells. Apoptosis. 2015;20(12):1599-1612. doi:10.1007/ s10495-015-1164-7

23. Wang Y, Wang H, Pan T, et al. Overexpression of PHRF1 attenuates the proliferation and tumorigenicity of non-small cell lung cancer cells. Oncotarget. 2016;7(39):64360-64370. doi:10.18632/oncotarget.11842

24. Czyzewska U, Siemionow K, Zareba I, et al. Proapoptotic activity of propolis and their components on human tongue squamous cell carcinoma cell line (CAL-27). PloS One. 2016;11(6):e0157091. doi:10.1371/journal.pone.0157091

25. Nagappan A, Lee HJ, Saralamma VV, et al. Flavonoids isolated from Citrus platymamma induced G2/M cell cycle arrest and apoptosis in A549 human lung cancer cells. Oncol Lett. 2016;12(2):1394-1402. doi:10.3892/ol.2016.4793

26. Rodriguez-Berriguete G, Torrealba N, Ortega MA, et al. Prognostic value of inhibitors of apoptosis proteins (IAPs) and caspases in prostate cancer: caspase-3 forms and XIAP predict biochemical progression after radical prostatectomy. BMC Cancer. 2015;15:809. doi:10.1186/s12885-015-1584-3
27. Wang J, Yuan L, Xiao H, et al. Momordin Ic induces HepG2 cell apoptosis through MAPK and PI3K/Akt-mediated mitochondrial pathways. Apoptosis. 2013;18(6):751-765. doi:10.1007/s10495-013-0820-Z

28. Yuan Y, Jiang CY, Xu H, et al. Cadmium-induced apoptosis in primary rat cerebral cortical neurons culture is mediated by a calcium signaling pathway. PloS One. 2013;8(5):e64330. doi:10.1371/journal.pone.0064330

29. Ospondpant D, Phuagkhaopong S, Suknuntha K, et al. Cadmium induces apoptotic program imbalance and cell cycle inhibitor expression in cultured human astrocytes. Environ Toxicol Pharmacol. 2019;65:53-59. doi:10.1016/j.etap.2018.12.001

30. Peng X, Zhang Q, Zeng Y, et al. Evodiamine inhibits the migration and invasion of nasopharyngeal carcinoma cells in vitro via repressing MMP-2 expression. Cancer Chemother Pharmacol. 2015;76 (6):1173-1184. doi:10.1007/s00280-015-2902-9

31. Duprez F, Berwouts D, De Neve W, et al. Distant metastases in head and neck cancer. Head Neck. 2017;39(9):1733-1743. doi:10.1002/hed.24687

32. Zhang C, Zhang Y, Ding W, et al. MiR-33a suppresses breast cancer cell proliferation and metastasis by targeting ADAM9 and ROS1. Protein Cell. 2015;6(12):881-889. doi:10.1007/s13238-015-0223-8

33. Fan Z, Duan X, Cai H, et al. Curcumin inhibits the invasion of lung cancer cells by modulating the PKCalpha/Nox-2/ROS/ATF-2/MMP-9 signaling pathway. Oncol Rep. 2015;34(2):691-698. doi:10.3892/or.2015.4044

34. Lin Z, Li W, Zhang H, et al. CCL18/PITPNM3 enhances migration, invasion, and EMT through the NF-kappaB signaling pathway in hepatocellular carcinoma. Tumour Biol. 2016;37(3):3461-3468. doi:10.1007/s13277-015-4172-x

35. Takai M, Terai Y, Kawaguchi H, et al. The EMT (epithelial-mesenchymal-transition)- related protein expression indicates the metastatic status and prognosis in patients with ovarian cancer. $J$ Ovarian Res. 2014;7:76. doi:10.1186/1757-2215-7-76

36. Yang WH, Sun L, Huang GH, et al. RAC1 activation mediates Twistl-induced cancer cell migration. Nat Cell Biol. 2012;14 (4):366-374. doi:10.1038/ncb2455

37. Yeungg KT, Yang J. Epithelial-mesenchymal transition in tumor metastasis. Mol Oncol. 2017;11(1):28-39. doi:10.1002/1878-0261.12017

38. Vaquero J, Guedj N, Claperon A, et al. Epithelial-mesenchymal transition in cholangiocarcinoma: from clinical evidence to regulatory networks. $J$ Hepatol. 2017;66(2):424 441. doi:10.1016/j.jhep.2016.09.010

39. Liu X, Yun F, Shi L, et al. Roles of signaling pathways in the epithelial-mesenchymal transition in cancer. Asian Pac J Cancer Prev. 2015;16(15):6201-6206. doi:10.7314/apjcp.2015.16.15.6201

40. Zhao L, Li Y, Song X, et al. Upregulation of miR-181c inhibits chemoresistance by targeting ST8SIA4 in chronic myelocytic leukemia. Oncotarget. 2016;7(37):60074-60086. doi:10.18632/oncotarget.11054

41. Zhou H, Wu J, Wang T, et al. CXCL10/CXCR3 axis promotes the invasion of gastric cancer via PI3K/AKT pathway-dependent MMPs production. Biomed Pharmacother. 2016;82:479-488. doi:10.1016/j. biopha.2016.04.069

42. Wei S, Wang L, Zhang L, et al. ZNF143 enhances metastasis of gastric cancer by promoting the process of EMT through PI3K/ AKT signaling pathway. Tumour Biol. 2016;37(9):12813-12821. doi:10.1007/s13277-016-5239-z

43. Wu YJ, Wong BS, Yea SH, Lu CI, Weng SH. Sinularin induces apoptosis through mitochondria dysfunction and inactivation of the $\mathrm{pI} 3 \mathrm{~K} / \mathrm{Akt} / \mathrm{mTOR}$ pathway in gastric carcinoma cells. Mar Drugs. 2016;14(8):142. doi:10.3390/md14040075

44. Camp E, Anderson PJ, Zannettino ACW, Gronthos S. Tyrosine kinase receptor c-ros-oncogene 1 mediates TWIST-1 regulation of human mesenchymal stem cell lineage commitment. Bone. 2017;94:98-107. doi:10.1016/j.bone.2016.09.019 


\section{Publish your work in this journal}

OncoTargets and Therapy is an international, peer-reviewed, open access journal focusing on the pathological basis of all cancers, potential targets for therapy and treatment protocols employed to improve the management of cancer patients. The journal also focuses on the impact of management programs and new therapeutic agents and protocols on patient perspectives such as quality of life, adherence and satisfaction. The manuscript management system is completely online and includes a very quick and fair peer-review system, which is all easy to use. Visit http://www.dovepress.com/ testimonials.php to read real quotes from published authors.

Submit your manuscript here: https:/www.dovepress.com/oncotargets-and-therapy-journal 